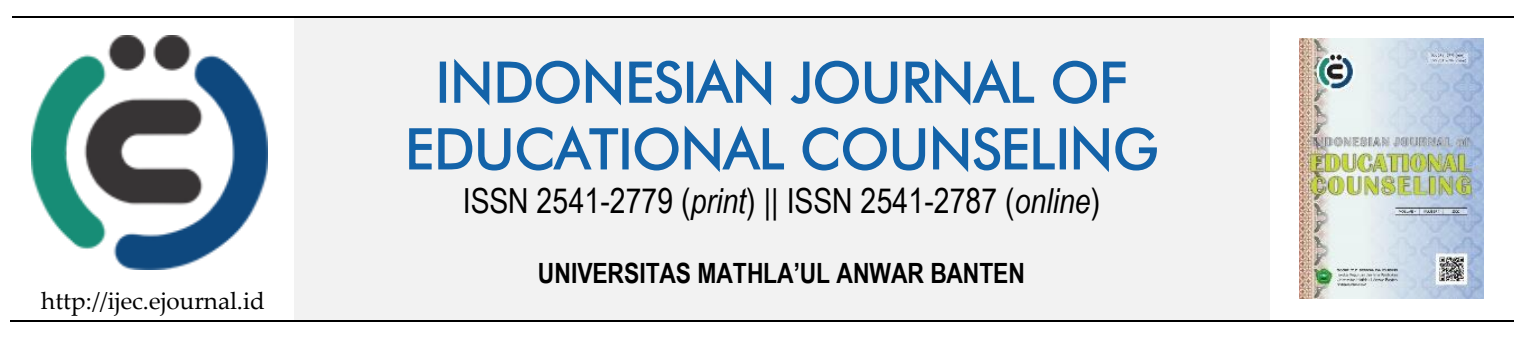

Research Based Article

\title{
Layanan Informasi berbasis Media Film Animasi untuk Mengembangkan Kemampuan Pemecahan Masalah Siswa SMK
}

\author{
Agus Wibowo ${ }^{1}$, Zulia Awaliana Muslikhah², Nurul Atieka ${ }^{3}$ \\ 1, 3 Universitas Muhammadiyah Metro, Indonesia, ${ }^{2}$ SMKN 3 Metro, Indonesia
}

\begin{tabular}{ll}
\hline Article History & ABSTRACT \\
\hline Received: 08.10.2019 & THE USING OF ANIMATION FILM IN INFORMATION SERVICE TO \\
Received in revised form: & IMPROVE PROBLEM SOLVING ABILITY OF VOCATIONAL SCHOOL \\
Accepted: 19.12.2019 & STUDENTS. The use of animated film in information services aims to ensure \\
Available online: 30.01.2020 & that massage of information service can be well received by students, and \\
& students have good motivation in participating in services. This study aims to \\
& determine the effectiveness of film animation in information services to \\
& improve the ability to abilty of problem solve students of SMKN 3 Metro in the \\
& academic year 2019/2020. The research method used action research. The \\
& research subjects were 30 students. The research instrument is a test of problem \\
& solving skills. The results of the study were an increase in average achievement \\
& scores, in the first cycle the average score of students 'ability to solve problems \\
& was 19.5, and the second cycle was 24.19 and the difference in the scores of \\
students' understanding scores in the second cycle with an ideal score of 7.05, \\
in the first cycle the difference between the score with the ideal score is 11.75. \\
Thus an increase between cycles I and II amounted to 4.70. The conclusion of \\
the research is the animation film in information service effective to improve \\
abilty problem solving of students SMKN 3 Metro academic year 2019/2020.
\end{tabular}

KEYWORDS: Animation Film, Information Service, Problem Solving.

DOI: $10.30653 / 001.202041 .119$

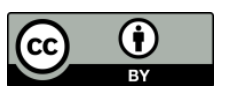

This is an open access article distributed under the terms of the Creative Commons Attribution 4.0 International License, which permits unrestricted use, distribution, and reproduction in any medium, provided the original work is properly cited. (C) 2020 Agus Wibowo, Zulia Awaliana Muslikhah, Nurul Atieka.

\section{PENDAHULUAN}

Perkembangan teknologi informasi yang secara signifikan telah hadir dan mewarnai kehidupan manusia secara signifikan merubah tata kehidupan dan kebiasaan hidup manusia. Sikap individualis, egosentris, dan kecemasan merupakan sisi buruk yang cenderung muncul akibat dari perubahan tata nilai yang diakibatkan oleh perubahan dan perkembangan teknologi informasi. Kebiasaan berkumpul, bercengkrama, berbagi, kepedulian sosial yang selama ini berlangsung dengan sistem atau cara "face to face" telah diubah dengan cara "online". Melalui media sosial, yang setiap orang cukup berdiam diri dirumah sudah dapat melakukan aktifitas yang selama ini dilakukan secara manual.

${ }^{1}$ Corresponding author's address: Program Studi Bimbingan dan Konseling, FKIP Universitas Muhammadiyah Metro. Iringmulyo, Kec. Metro Tim., Kota Metro, Lampung 34381, Indonesia. Email: bowokhoirunnas_khairunnasgec@ rocketmail.com 
Perubahan kondisi memiliki dampak bagi remaja yang harus mendapatkan perhatian dan antisipasi agar remaja dapat menjadi individu yang tumbuh dan berkembang fisik dan psikisinya secara optimal.

Objek perhatian dan antisipasi akibat perubahan tata kehidupan pada era digitalisasi dikalangan remaja didasarkan pada kondisi remaja yang masih dalam tahapan menemukenali dirinya, masa transisi, dan masa-masa belum stabil secara mental dan emosional. Pada masa-masa ini remaja sangat rentan dihadapkan pada pilihan-pilihan hidup. Dihadapkan pada kondisi dan situasi yang menuntut remaja dapat menyelesaikan dan menuntaskannya, sebagai prasyarat untuk dapat memasuki tahapan dewasa. Remaja cenderung dengan karakter keras, berani mencoba, namun kurang dalam hal perhitungan matang dalam memilih dan melakukan keputusan-keputusan hidup yang diambil. Dan kondisi tersebut pada dasarnya membutuhkan orang lain untuk membantu, berbagi, dan bertukar pikiran dalam menentukan pilihan-pilihan hidup.

Mengkaitkan dua kondisi antara perkembangan jaman yang serba berbasis online dan digitalisasi dengan karakteristik yang dimiliki oleh remaja yang berada pada masa transisi yang membutuhkan relationship dalam kehidupannya, disitulah kecenderungan muncul masalah-masalah yang akan dihadapi oleh remaja. Kebutuhan berhubungan sosial, bertemu dan saling berbagi dengan orang lain pada saat ini merupakan sesuatu yang sangat jarang ditemui pada dunia remaja, sehingga sifat ketergantungan akan media sosial pada dasarnya menyebabkan beberapa tugas perkembangan remaja tidak terpenuhi. Akan tetapi, tentu perubahan jaman tidaklah bias dicegah atau dihindari, namun secara cerdas dan strategis hendaknya dirumuskan cara-cara agar remaja memiliki kemampuan dalam menghadapi permasalahan-permasalahan yang dialami secara mandiri.

Salah satu strategis yang dapat dilakukan untuk membangun remaja yang tangguh dalam era teknologi informasi dan digitalisasi adalah dengan memberikan pemahaman cara pemecahan masalah (problem solving). Dengan membekali kemampuan memecahkan masalah, ketika dihadapkan pada masalah-masalah rermaja sudah memiliki bekal yang cukup untuk menghadapinya, secara mandiri telah akan mampu merancang strategi pemecahan masalah dan tidak bergantung pada orang lain. Kemampuan pemecahan masalah bagi remaja merupakan bentuk kualitas dari berfikir kritis. Pemecahan masalah yang baik diawali dari kemampuan mengkritisi keadaan yang menimpa dirinya, kemudian mendiagnosa hal-hal terkait dengan masalah yang dialami, serta secara mandiri memilih alternative-alternatif pemecahaman masalah. Hal tersebut diperkuat Santrock (2011) menjelaskan bahwa pemikiran kritis adalah pemikiran reflektif dan produktif, serta melibatkan evaluasi bukti. Kemampuan pemecahan masalah individu tidak akan dapat dilakukan secara efektif jika individu tidak memiliki kemampuan untuk memperhitungan berbagai alternatif dan juga konsekuensi yang diterima jika telah memenetapkan alternatif-alternatif pemecahan masalah.

Masalah merupakan kesenjangan antara ekpektasi dan realita yang kemudian mengganggu produktivitas individu. Anderson (2009) menjelaskan pentingkan individu memiliki kemampuan pemecahaman masalah, karena pemecahaman masalah merupakan keterampilan hidup yang melibatkan proses menganalisis, menafsirkan, menalar, memprediksi, mengevaluasi dan merefleksikan. Dengan demikian, pemecahaman masalah akan dapat membantu peserta didik ketika individu dihadapkan pada kondisi ingin memiliki suatu keinginan (need), melakukan upaya pemenuhan 
keinginan, dan dihadapkan pada hasil yang diperoleh tidak sesuai dengan apa yang diinginkan.

Penguatan kemampuan peserta didik dalam mengatas masalah merupakan upaya yang sangat penting. Guru Bimbingan dan Konseling merupakan salah satu pihak yang memiliki kompetensi untuk mengembangkan kemampuan peserta didik dalam meningkatkan kemampuan peserta didik dalam mengatasi masalah. Upaya yang dilakukan oleh guru Bimbingan dan Konseling dalam mengatasi masalah dapat dilakukan melalui layanan informasi. Tohirin (2009) menjelaskan bahwa layanan informasi ialah usaha-usaha membekali siswa dengan pengetahuan serta pemahaman tentang lingkungan hidupnya dan tentang proses perkembangan anak muda. Pelaksanaan layanan informasi dilakukan oleh guru Bimbingan dan Konseling memiliki fungsi agar peserta didik memiliki pemahaman akan dirinya, baik bidang pribadi, sosial, belajar, dan karier.

Pelaksanaan layanan informasi oleh guru Bimbingan dan Konseling pada umumnya dilaksanakan dengan menggunakan metode ceramah dan dengan modus atau format layanan klasikal. Kecenderungan pelaksanaan layanan informasi yang bersifat monoton kerap menimbulkan rasa antusias dan minat peserta didik rendah. Hal tersebut, juga dikeluhkan oleh guru Bimbingan dan Konseling SMK Negeri 03 Metro. Berdasarkan wawancara dan diskusi dengan guru Bimbingan dan Konseling SMK Negeri 03 Metro pada tanggal 09 September 2019 diperoleh keterangan bahwa: 1) siswa cenderung kurang aktif dalam kegiatan layanan BK menggunakan ceramah, 2) guru cenderung susah dalam menentukan media layanan BK yang bisa menimbulkan antusias dan semangat mengikuti layanan, dan 3) tingkat pemahaman peserta didik terhadap materi layanan masih kurang maksimal. Berangkat dari permasalahan yang diungkapkan oleh guru Bimbingan tersebut, maka peneliti tertarik untuk melakukan penelitian tindakan kelas (action research) dengan berkolaborasi dengan guru Bimbingan dan Konseling dengan menerapkan media layanan berupa film animasi. Kustandi (2011) film adalah serangkaian gambar "hidup" (motion pictures). Film diharapkan dapat mendorong peserta didik terbawa dalam suasana nyata yang dibangun dalam setiap kejadian-kejadian yang ditayangkan.

Pemilihan film animasi sebagai media layanan diharapkan dapat meningkatkan motivasi dan antusias peserta didik dalam mengikuti layanan. Dengan demikian, pesert didik akan berminat mengikuti layanan yang diselenggarakan oleh guru Bimbingan dan Konseling. Hurlock (dalam Hidayati, 2012) menyebutkan bahwa minat mempunyai dua aspek yaitu aspek kognitif dan aspek afektif sehingga penguasaan atau pemahaman individu terhadap suatu hal terkait dengan minat pada diri peserta didik pada suatu hal tersebut. Melalui penggunaan media film dapat membangkitkan minat peserta didik, dan diharapkan materi yang diberikan dapat diterima dan dipahamai oleh peserta didik dengan maksimal.

\section{METODE}

Rancangan dalam penelitian ini adalah rancangan peneliti dengan menggunakan tindakan yang diterapkan dalam layanan sehingga penelitian ini menggunakan desain penelitian tindakan layanan (PTL). Menurut Arikunto (2006) penelitian tindakan adalah kajian tentang situasi sosial dengan maksud untuk meningkatkan kualitas tindakan di 
dalamnya. Dilakukannya PTK/PTL adalah dalam rangka guru besedia untuk mengintropeksi, bercermin, merefleksi atau mengevaluasi dirinya sendiri sehingga kemampuannya sebagai guru diharapkan cukup profesional.

Untuk mewujudkan tujuan dari penelitian tindakan maka pelaksanaan proses pengkajian dilakukan secara berdaur (cyclical) yang terdiri dari 4 tahapan sebagai berikut yaitu: perencanaan (planning), tindakan (action), pengamatan (observation), dan refleksi (reflection). Subjek penelitian yaitu siswa kelas XII TITLB SMK Negeri 3 Kota Metro Tahun Pelajaran 2019/2020 yang berjumlah 30 siswa. Instrumen pengumpulan data tes kemampuan memecahkan masalah dengan tipe multiple choice. Teknik analisis data dilakukan dengan mencari nilai rata-rata dan dinterpretasikan secara deskriptif.

\section{HASIL DAN PEMBAHASAN}

\section{Hasil Penelitian}

Kegiatan penelitian tindakan kelas dilakukan melalui empat tahapan dan dilaksanakan dengan dua siklus.

\section{Siklus I}

Pada siklus I, penelitian melaksanaan tahapan peneiltian tindakan kelas, yang secara rinci disajikan sebagai berikut:

Perencanaan

Sebelum proses pemberian layanan informasi dilaksanakan peneliti melakukan perencanaan sebagai berikut:

1) Mempersiapkan perangkat layanan informasi;

2) Menentukan media film animasi yang akan digunakan. Pada layanan pertama yang digunakan adalah film animasi dengan judul " Masalah dan kehidupan";

3) Menyiapkan perangkat evaluasi;

4) Berkordinasi dengan pihak-pihak terkait, sepertiwali kelas dan wakil kepala sekolah bagian kurikulum.

Pelaksanaan layanan

Pelaksanaan layanan informasi sesuai dengan tahapan perencanaan yang sudah ditentukan akan dilaksanakan pada tanggal 06 September 2019 dengan waktu layanan adalah satu jam pelajaran. Pada pelaksanaan layanan informasi yang pertama, peneliti menggunakan layanan informasi dengan materi layanan Pemahaman tentang konsep masalah dan penyebabnya. Media layanan yang digunakan adalah media film animasi berjudul "Masalah dan kehidupan". Jumlah peserta didik yang ikut pada layanan informasi pada siklus I berjumlah 30 peserta didik.Kompetensi yang diharapkan pada layanan informasi pada siklus I yaitu: 1) Peserta didik memahami konsep masalah pada diri individu, 2) Peserta didik secara aktif mampu mengidentifikasi penyebab dan jenis masalah yang dialami individu. 
Observasi

Setelah diberikan layanan, selanjutnya tahapan observasi. Pada tahap ini peneliti melakukan tes kemampuan pemahaman pemecahan masalah ada peserta didik. Tes ini bertujuan untuk mengukur kemampuan peserta didik dalam memecahkan masalah setelah diberikan perlakuan. Tes yang diberikan adalah tes kemampuan pemecahan masalah dengan jumlah soal 25 yang terdiri dari 6 soal pada indikator identifikasi masalah, 6 soal pada indikator diagnosis masalah, 6 soal pada indikator menentukan alternative pemecahaman masalah, dan 7 soal pada indikator pemilihan solusi masalah. Berdasarkan tes yang dilakukan, maka diperoleh data yang disajikan pada Tabel 1.

Tabel 1. Rekapitulasi hasil tes pemahaman memecahkan masalah siklus I peserta didik kelas XII TITLB SMK N 3 Kota Metro Tahun Pelajaran 2019/2020

\begin{tabular}{llll}
\hline Indikator & Skor Ideal & Rata-rata pencapain Skor & Gain \\
\hline Mengidentifikasi masalah & 30 & 18,23 & 11,77 \\
\hline Diagnosa masalah & 30 & 19,63 & 10,37 \\
\hline Menentukan alternatif & 30 & 19,87 & 10,13 \\
\hline Menentukan solusi & 35 & 20,27 & 14,73 \\
\hline
\end{tabular}

Data yang disajikan pada Tabel 1, menunjukkan bahwa setelah diberikan layanan informasi dengan media film animasi terlihat pada pada setiap indikator nilai rata-rata yang diperoleh mahasiswa masih cukup jauh perbedaannya dengan skor ideal yang diharapkan, dengan rata-rata perbedaannya adalah 11,75. Perbedaan antar skor ideal dengan rata-rata skor peserta didik terlihat pada diagram dibawah ini:

Data di atas menunjukkan bahwa layanan informasi yang diberikan masih belum membantu peserta didik memahami cara memecahkan masalah secara optimal. Perbedaan antara skor yang diharapkan dengan skor peserta didik masih nampak cukup besar.

Refleksi

Berangkat dari hasil yang dicapai dari tes yang dilakukan pada siklus layanan informasi yang pertama, maka upaya untuk meningkatkan hasil layanan akan dilakukan perbaikan layanan sebagai berikut:

1) Durasi film dibuat hanya sekitar 5 menit. Pada tahap I durasi film mencapai 10;

2) Setelah menonton film, maka segera dilanjutkan kegiatan diskusi;

3) Guru segera memposisikan diri sebagai fasilitator pada saat peserta didik menonton dan juga berdiskusi. Sehingga nilai-nilai yang dipesankan oleh film dapat dimaknai secara benar dan utuh oleh peserta didik.

\section{Siklus II}

Pelaksanaan layanan informasi pada siklus II disajikan sebagai berikut:

Perencanaan

Pada tahap perencanaan siklus II diarahkan pada perbaikan pelaksanaan layanan informasi pada siklus I. Sebelum proses pemberian layanan informasi dilaksanakan peneliti melakukan perencanaan sebagai berikut: 
1) Mempersiapkan perangkat layanan informasi;

2) Menentukan media film animasi yang akan digunakan. Pada layanan pertama yang digunakan adalah film animasi dengan judul "Cara Menghadapi Masalah" dan memperpendek durasi film;

3) Menyiapkan perangkat evaluasi;

4) Berkordinasi dengan pihak-pihak terkait, sepertiwali kelas dan wakil kepala sekolah bagian kurikulum;

5) Mempersiapkan bahan diskusi.

Pelaksanaan layanan

Pelaksanaan layanan informasi pada siklus II dilaksanakan pada tanggal 13 September 2019 dengan waktu layanan adalah satu jam pelajaran. Proses pelaksanaan layanan menggunakan metode diskusi, yang dilakukan setelah peserta didik menyaksikan tayangan film. Pada sesi pemutaran film yang dilakukan oleh peniliti adalah memberikan ulasan singkat terkait kejadian-kejadian penting dan menarik yang ada dalam film, sehingga peserta didik memahami isi dan pesan yang ingin disampaikan dari film tersebut.

Setelah menyaksikan tayangan film, dilanjutkan dengan membentuk kelompok diskusi dan memberikan bahan diskusi kepada kelompok peserta didik. Kemudian hasil diskusi disampaikan kedepan kelas sebagai bentuk laporan diskusi dan diberikan tanggapan oleh kelompok lain. Materi yang diskusikan adalah mengenai tahapan pemecahan masalah, yaitu: 1) cara mengidentifikasi masalah, 2) cara melakukan diagnosis masalah, 3) cara memilih dan menyusun alternative pemecahan masalah, dan 4) menentukan alternative terbaik untuk menyelesaikan masalah. Dengan kegiatan diskusi, peserta didik nampak antusias dan lebih aktif dalam menyampaikan ide-ide yang mereka peroleh dan terinspirasi dari film.

\section{Observasi}

Pada tahap observasi, peneliti selanjutnya memberikan tes kepada peserta didik agar mengetahui tingkat keberhasilan dari layanan informasi yang diberikan. Tes yang diberikan adalah tes kemampuan pemecahan masalah dengan jumlah soal 25 yang terdiri dari 6 soal pada indikator identifikasi masalah, 6 soal pada indikator diagnose masalah, 6 soal pada indikator menentukan alternative pemecahaman masalah, dan 7 soal pada indikator pemilihan solusi masalah. Berdasarkan tes yang dilakukan, maka diperoleh data sebagai berikut:

Tabel 2. Rekapitulasi hasil tes pemahaman memecahkan masalah siklus II peserta didik kelas XII TITLB SMK N 3 Kota Metro Tahun Pelajaran 2019/2020

\begin{tabular}{llll}
\hline Indikator & Skor Ideal & Skor nyata & Gain \\
\hline Mengidentifikasi masalah & 30 & 24,47 & 5,53 \\
\hline Diagnosa masalah & 30 & 23,23 & 6,77 \\
\hline Menentukan alternatif & 30 & 24,67 & 5,33 \\
\hline Menentukan solusi & 35 & 24,4 & 10,6 \\
\hline
\end{tabular}


Pada Tabel 2, terlihat perbedaan yang cukup signifikan capaian pemahaman peserta didik jika dibandingkan dengan siklus I. Perbedaan capaian skor pemahaman peserta didik pada siklus II dengan skor ideal yaitu sebesar 7,05, pada siklus I perbedaan capaian skor dengan skor ideal adalah sebesar 11,75. Dengan demikian terjadi peningkatan antara siklus I dan II sebesar 4,70. Selain itu peningkatan juga terlihat dari rata-rata capaian skor, pada siklus I rata-rata skor kemampuan peserta didik memecahkan masalah sebesar 19,5, dan siklus II sebesar 24,19.

Data di atas menunjukkan bahwa layanan informasi yang diberikan cukup membantu peserta didik memahami cara memecahkan masalah secara optimal. Perbedaan antara skor yang diharapkan dengan skor peserta didik tidak terlalu terjadi perbedaan yang cukup besar.

Refleksi

Berangkat dari hasil yang dicapai dari tes yang dilakukan pada siklus layanan informasi yang kedua, telah terjadi peningkatan yang cukup baik. Hal tersebut terlihat dari pencapaian skor kemampuan peserta didik untuk memecahkan masalah.

Berdasarkan hasil analisis data di atas, maka media film animasi dalam pelaksanaan layanan informasi efektif untuk meningkatkan pemahaman peserta didik dalam memecahkan masalah. Hal terpenting yang diperhatikan adalah dalam menggunakan media film, guru Bimbingan dan Konseling harus bias menjelaskan materi atau pesan dari film kepada peserta didik dengan baik dan jelas. Selain itu, tindaklanjut dari kegiatan menonton film harus diberikan kegiatan diskusi kepada peserta didik agar lebih memahami maksud materi layanan yang disajikan dalam film.

\section{Pembahasan}

Kemampuan memecahkan masalah adalah bentuk kemandirian peserta didik yang menjadi indikator penting dalam tugas perkembangan. Pada kegiatan assesmen yang dilakukan pada siklus I, diketahui bahwa kemampuan peserta didik memahami masalah masih cukup rendah. Hayat (2007) mendefinisikan bahwa munculnya masalah adalah ketika terjadi kesenjangan dan ketidakseesuaian antara apa yang dipikirkan dengan realita. Peserta didik yang mengalami masalah tentu akan mengalami hambatanhambatan dalam tugas perkembangannya.

Upaya meningkatkan kemampuan peserta didik dalam memecahkan masalah menjadi sangat penting. Hal ini disebabkan peserta didik sedang dalam proses kehidupan yang berkenaan dengan berbagai tuntutan-tuntutan hidup, baik dilingkungan keluarga, lingkungan sosial, dan juga dilingkungan pendidikan. Hawari (1997) menjelaskan bahwa kondisi pekerjaan dengan waktu yang sangat sempit, ditambah lagi dengan tuntutan merupakan kondisi yang sangat rentang menimbulkan stress pada diri remaja.

Oleh karena hal tersebut di atas, guru Bimbingan dan Konseling hendaknya memahami kondisi remaja tersebut dan secara inovatif memberikan treatmen yang mampu membekali peserta didik atau remaja dalam menghadapinya masalah. Upaya yang dilakukan pada layanan informasi dengan menggunakan film pada siklus yang pertama belum berhasil secara signifikan. Hal tersebut cenderung disebabkan durasi film yang agak lama dan minimnya penjelasan yang diberikan. Film adalah media yang cukup menarik, dan mampu menyampaikan pesan-pesan secara mendalam dan mengena pada diri peserta didik. Media dilm merupakan media yang mengandung pesan sebagai perangsang sehingga dapat menumbuhkan motivasi belajar pada siswa (Trianto, 2013). 
Namun dalam penggunaannanya harus disertai penjelasan yang baik, sehingga makna dan pesan dari film dapat dicerna oleh peserta didik. Pada layanan informasi yang pertama guru kurang memberikan penjelasanakan materi atau pesan, sehingga maksud dan pesen film kurang dipahami. Namun pada siklus yang ke II, guru lebih aktif memberikan penjelasan-penjelasan pada peserta didik ketika ada kejadian yang menarik pada film. Dengan demikian maksud yang ingin disampaikan dalam film dapat dipahami oleh peserta didik.

\section{SIMPULAN}

Penggunaan media film animasi dalam pelaksanaan layanan informasi efektif untuk meningkatkan pemahaman pemecahan masalah peserta didik. Melalui media film animasi, peserta didik dapat memperoleh pengalaman secara nyata melalui kejadiankejadian yang ditayangkan. Penggunaan media film mendorong peserta didik lebih antusias mengikuti layanan informasi, menjadi lebih aktif, dan tingkat penguasaan materi layanan menjadi lebih baik.

Tingkat efektiftitas penggunaan media film salah satunya ditentukan oleh kualitas guru BK dalam menjelaskan makna dan pesan yang dimaksud dalam film. Oleh karena itu guru BK harus memahami terlebih dahulu isi dan makna dari film yang akan disajikan.

\section{REFERENSI}

Arikunto, S. (2006). Penilaian dan penelitian bidang bimbingan dan konseling. Yogyakarta: Aditya Media.

Anderson, J. (2009). Mathematics curriculum development and the role of problem solving. ACSA Conference.

Djamrah, S. B. (2008). Psikologi belajar, Edisi 2. Jakarta: Rineka Cipta.

Hidayati, A. (2012). Efektifitas bimbingan kelompok dalam meningkatkan minat memanfaatkan layanan konseling. Surakarta: Universitas Muhammadiyah Surakarta.

Kustandi, C., \& Sutjipto, B. (2011). Media pembelajaran manual dan digital. Bogor: Ghalia Indonesia.

Prasetya, A., Kartono., \& Widodo, A. T. (2012). Model IDEAL problem solving untuk pencapaian kemampuan pemecahan masalah di kelas olimpiade. Jurnal Lembaran Ilmu Kependidikan, 41(1), 1-6.

Santrock, J. W. (2011). Educational psychology. New York: McGraw Hill.

Sardiman, A. M. (2001). Interaksi dan motivasi belajar mengajar. Jakarta: Raja Grafindo Persada.

Tohirin. (2009). Bimbingan dan konseling di sekolah madrasah. Jakarta: Raja Grafindo Persada.

Trianton, T. (2013). Film sebagai media belajar. Yogyakarta: Graha Ilmu. 